\title{
Dwie dusze socjaldemokracji. 150 lat i wszystko na nic?
}

Choć tradycyjnie pojęte badania nad historią polityczną, koncentrujące swoją uwagę na losach rządów, parlamentów, organizacji partyjnych i ich przywódców od dłuższego już czasu spychane są nieco na margines światowej historiografii, to zainteresowanie dziejami niemieckiej socjaldemokracji zdaje się wcale nie maleć - kolejne lata, jakby na przekór trendom, przynoszą wciąż nowe opracowania poświęcone stupięćdziesięcioletniej historii SPD. Niezwykła długowieczność nie jest jednak najważniejszym źródłem niesłabnącego zainteresowania kolejnych pokoleń badaczy dziejami tej partii. Fenomen SPD polega przede wszystkim na tym, że była to pierwsza, nowoczesna, masowa partia socjaldemokratyczna na świecie, przez długie dziesięciolecia traktowana jak niedościgniony wzór - zarówno pod względem programowym, jak i organizacyjnym - dla całego ruchu socjalistycznego ${ }^{1}$. Od końca XIX stulecia rozwiązania wypracowane przez SPD starano się wcielać w życie, z różnym powodzeniem, w partiach socjalistycznych całej Europy. Dość powiedzieć, że nawet brytyjscy laburzyści, tak dumni z odrębności swej partii, ukształtowanej w atmosferze wyspiarskiego liberalizmu

1 W niniejszej recenzji pojęcia „socjalizm” i „socjaldemokracja” traktowane będą - podobnie jak ma to zwykle miejsce w literaturze przedmiotu - synonimicznie. 
SPD przez dekady była również awangardą ruchu socjalistycznego jeśli chodzi o debaty

programowe.

To przede wszystkim

w jej szeregach

kładziono fundamenty pod ortodoksję Drugiej

Międzynarodówki,

to tutaj też narodził się teoretyczny rewizjonizm z jednej i zdecydowanie rewolucyjna "lewica socjalistyczna" z drugiej strony i pragmatyzmu, w latach dwudziestych z fascynacją przyglądali się organizacyjnej sprawności niemieckiej SPD, gorliwie zabierając się do wcielania w życie podobnych wzorców również we własnej partii².

SPD przez dekady była również awangardą ruchu socjalistycznego jeśli chodzi o debaty programowe. To przede wszystkim w jej szeregach kładziono fundamenty pod ortodoksję Drugiej Międzynarodówki, to tutaj też narodził się teoretyczny rewizjonizm z jednej i zdecydowanie rewolucyjna „lewica socjalistyczna” z drugiej strony. SPD jako jedna z pierwszych partii socjalistycznych mierzyła się z problemem niewydolności międzywojennej demokracji parlamentarnej, ona też znalazła się po II wojnie światowej na czele pochodu - odbywanego nieco zygzakiem i w nierównym tempie - ku pojednaniu europejskiej socjaldemokracji z kapitalizmem. Wszystko to sprawia, że pisanie dziejów SPD zawsze będzie poniekąd również pisaniem historii europejskiego ruchu socjalistycznego jako całości. Ruchu, który w dziewiętnastym wieku zrodził się ze szlachetnego marzenia o świecie wolnym od wyzysku, przemocy i ubóstwa, a który dziś zdaje się tkwić w martwym punkcie - pozbawiony już nadziei na lepsze jutro, lecz wciąż jeszcze zbyt silny, aby można było go po cichu odesłać do lamusa historii.

Odbyte w maju 2013 roku oficjalne obchody sto pięćdziesiątej rocznicy powstania SPD, jakby wbrew tej ponurej diagnozie, obchodzone były z rozmachem i w podniosłej atmosferze. Przypominano zasługi legendarnych przywódców - Lassalle’a, Bebla, Brandta - i przekonywano się wzajemnie, że socjaldemokracja jest wciąż jeszcze ważna i potrzebna. Wszystkiemu dodawała splendoru obecność niemieckiej kanclerz, francuskiego prezydenta i szeregu innych oficjeli. O tym jednak, że więcej było w tym robienia dobrej miny do złej gry, niż faktycznego optymizmu, przekonać może lektura polskiego tłumaczenia „biografii” (jak głosi niemiecki tytuł ${ }^{3}$ ) SPD pióra niemieckiego historyka i politologa, Franza Waltera, kierownika Instytutu Badań nad Demokracją na Uniwersytecie w Getyndze, posiadającego w dorobku kilkanaście książek poświęconych niemieckiej socjaldemokracji. Wydanie „biografii” SPD, będącej poniekąd syntetycznym podsumowaniem wieloletnich badań autora, wsparło polskie przedstawicielstwo Fundacji im. Eberta, właśnie w celu uczczenia jubileuszu partii. Myliłby się jednak ten, kto uznałby, że jest to ciepła laurka dla szacownej i dobrodusznej jubilatki. Pochwały bowiem Walter dozuje bardzo oszczędnie, a całą książkę zdaje się przenikać żal za świet-

2 Zob. Organising Talent and Disciplined Steadiness: The German SPD as a Model for the British Labour Party in the 1920s?, „Contemporary European History" 1996, vol. 5, no. 2.

3 Tytuł oryginału brzmi: Die SPD. Biographie einer Partei. 
ną, a utraconą już przeszłością i pragnienie odnalezienia odpowiedzi na najważniejsze pytanie: dlaczego się nie udało?

\section{Bunt czeladników i socjaldemokratyczny romantyzm}

Niemiecka socjaldemokracja, wbrew temu, co mogłoby się wydawać, nie zrodziła się wcale w środowisku wielkoprzemysłowej klasy robotniczej i nie od razu też nabrała zdecydowanie marksistowskiego oblicza ideowego. Impulsem, z którego zrodzić się miał w konsekwencji nowoczesny, masowy ruch robotniczy w Niemczech, był w istocie skierowany przeciwko industrializmowi bunt czeladników, rozgoryczonych z powodu gwałtu, jaki ich dawnym prawom i tradycyjnym przywilejom zadawał nabierający rozpędu kapitalizm ${ }^{4}$. Tym, który dostrzegł ogromny potencjał $\mathrm{w}$ tym buncie i potrafił nadać całemu ruchowi zdecydowanie ofensywny charakter, był wzięty adwokat z Wrocławia, Ferdynand Lassalle.

Lassalle był bez wątpienia człowiekiem o nieprzeciętnej osobowości, jednak mało kto mógłby przypuszczać, że ktoś taki będzie pierwszym przywódcą i ideowym patronem nowoczesnej socjaldemokracji. Był błyskotliwym i porywającym mówcą, ale jednocześnie miał w sobie coś z dandysa, cenił rozkosze życia wielkomiejskiej bohemy i nie gardził towarzystwem atrakcyjnych kobiet. Politykę Lassalle traktował trochę jak sztukę, a trochę jak rozrywkę pozwalającą mu zaspokoić własne ambicje. Miał jednak potężną charyzmę i potrafił natchnąć członków założonego przez siebie Powszechnego Niemieckiego Związku Robotniczego wiarą, że świat dobrobytu i społecznej sprawiedliwości jest na wyciągnięcie ręki. Robotnicy go uwielbiali, „żelazny kanclerz” Bismarck cenił, a tylko jeden Karol Marks szczerze go nienawidził, widząc w Lassalle'u przede wszystkim awanturnika, naiwnego romantyka i nieodpowiedzialnego komedianta. Lassalle, jakby chcąc te nieprzychylną opinię potwierdzić, dał się zastrzelić w 1864 roku w pojedynku stoczonym o kobietę . Zmarł jeszcze zanim socjaldemokracja zdążyła nabrać rozpędu, jednak pamięć o nim długo jeszcze trwała w całym ruchu. Dopiero w 1875 doszło do połączenia „lassallistów” i „eisenachczyków”, należących do stronnictwa powołanego przez bliższych socja-

4 F. Walter, SPD: Z historii niemieckiej socjaldemokracji, tłum. M. Sutowski, Warszawa 2013, s. 9-11.

5 Szczegółowo na temat okoliczności pojedynku: G. von Uexküll, Lassalle, Warszawa 1987 , s. 126-135. 
lizmowi naukowemu Marksa Augusta Bebla i Wilhelma Liebknechta ${ }^{6}$. Od tego momentu niemiecka socjaldemokracja nabierać zaczęła coraz wyraźniej wielkomiejskiego, robotniczego, a powoli również marksistowskiego pod względem ideowym oblicza.

Zagrożenie, jakie stanowić mogła dla konserwatywnego porządku politycznego kajzerowskich Niemiec, rozpoznane zostało bardzo szybko, nic dziwnego więc, że w 1878 roku Bismarck skorzystał z pretekstu, jakim był nieudany zamach na cesarza, aby przeforsować ustawę zakazującą działalności socjalistycznej. „Kosmopolityczni nicponie” ${ }^{7}$, jak nazwano socjaldemokratów, musieli uchodzić zagranicę albo przejść do konspiracji. Jednak Bismarck spóźnił się o kilka lat - zlikwidowanie decyzją administracyjną wielotysięcznego ruchu społecznego nie było już możliwe. Gdy po dwunastu latach uchylono antysocjalistyczne ustawodawstwo, socjaldemokracja odrodziła się znacznie silniejsza, niż przed delegalizacją. Wkrótce zaś miała się stać tak potężna, jaką nie była zapewne nawet w najgorszych koszmarach „żelaznego kanclerza”.

Dwanaście lat konspiracji to okres kluczowy w dziejach niemieckiej socjaldemokracji. Ukształtowało się wówczas jej programowe oblicze wyraźnie marksistowskie, w kategoriach klasowych interpretujące instytucję państwa i nieufne wobec wszelkich warstw nierobotniczych. Jak pisze Walter, „[o]d tamtego czasu społeczeństwo dzieliło się wyraźnie na dobrych i złych, na "nas i innych"”. Tych dwanaście lat wzmocniło zwartość socjaldemokratycznych szeregów, pozwalając jednocześnie zbudować partyjną mitologię - osnutą wokół toposów szlachetnego cierpienia i gotowości do poświęcenia w imię wyznawanych wartości.

\section{Społeczeństwo alternatywne}

Po tych dwunastu latach już tylko jak naiwna romantyka brzmieć musiały głoszone przez Lassalle’a projekty porozumienia z Bismarckiem i odgórnego wprowadzania „socjalizmu” w sojuszu z konserwatywnymi elitami Cesarstwa. Wyzwolenie robotników, zgodnie z Marksowską formułą, stać się miało dziełem ich samych, a stary świat zginąć miał pod ciosami przyszłej rewolucji, jak głosił przyjęty w 1891 roku Program Erfurcki, napisany wspólnie przez Kautsky’ego i Bernsteina, będący przez długie lata wzorem, na którym opierały się programy

6 F. Walter, SPD, s. 15-16.

7 Tamże, s. 19. 
większości europejskich partii socjalistycznych ${ }^{8}$. W związku z tym jednak, że na rewolucję się na razie nie zanosiło, a „obiektywne” przesłanki socjalizmu wciąż jeszcze nie były ukształtowane, niemieccy socjaldemokraci zabrali się do budowy „alternatywnego społeczeństwa” w łonie kapitalizmu. Na przełomie wieków Niemcy zaczęły pokrywać się gęstą siecią robotniczych klubów, towarzystw śpiewaczych, sportowych i turystycznych, spółdzielni, kół i grup oświatowych, amatorskich teatrów, redakcji socjalistycznych gazet itd. Całe to „alternatywne społeczeństwo" opierało się materialnie przede wszystkim o rosnące w szybkim tempie związki zawodowe, a jego polityczną nadbudową była zbliżająca się do miliona członków SPD.

Istnienie tego imponującego świata autonomicznej robotniczej kultury nie musiało jednak wcale oznaczać zbliżania się ku socjalizmowi. Dawał on poczucie niezależności, stabilności i pewnej wygody, odsuwając jednocześnie rewolucyjne plany na daleką przyszłość. Jak pisze Walter, socjaldemokraci „[z]budowali sobie własną ojczyznę, uczynili swą kulturalną i społeczną niszę zdatną do mieszkania. I nie wystawili tego wszystkiego na nieobliczalne ryzyko rewolucji” " ${ }^{9}$. Na przełomie wieków coraz wyraźniej widać było - konstytutywne dla socjalizmu demokratycznego w całej Europie - pęknięcie pomiędzy szczerą wiarą w zwycięską rewolucję i radykalną transformację społeczeństwa a codzienną praktyką, obliczoną na poprawę położenia robotników, demokratyzację systemu politycznego i uzyskanie możliwie dobrego wyniku w najbliższych wyborach. Zwornikiem, który zdawał się łączyć teorię i praktykę, był deterministycznie odczytywany marksizm a là Kautsky, wiążący tryumf socjalizmu z „obiektywnymi” prawami rozwoju społecznego, jednocześnie jednak usprawiedliwiający bierność socjaldemokracji. SPD była wówczas, jak twierdzi Walter, „kolosem w stanie oczekiwania”.

Pasywna taktyka europejskiej socjaldemokracji kontestowana była przez dekady z różnych pozycji. W SPD przełomu wieków najpoważniejszymi jej krytykami były postaci o krańcowo różnym temperamencie - Eduard Bernstein i Róża Luksemburg ${ }^{10}$. Ojciec rewizjonizmu pragnął, aby SPD wyszła z izolacji i, w porozumieniu z środowiskami liberalnymi, podjęła próbę reformy systemu politycznego Cesarstwa. Projekt „ewolucyjnego socjalizmu” ${ }^{11}$ Bernsteina opierał się na postula-

8 M. Waldenberg, Wzlot i upadek Karola Kautsky'ego: Studium z historii myśli spotecznej i politycznej, t. 1, Kraków 1972, s. 87-100.

9 F. Walter, SPD, s. 23.

10 Zob. P. Nettl, The German Social Democratic Party 1890-1914 as a Political Model, „Past and Present”, 1965, no. 30.

11 Drobiazgową analizę koncepcji „ewolucyjnego socjalizmu” przeprowadza
Istnienie tego

imponującego świata autonomicznej

robotniczej kultury nie musiało jednak wcale oznaczać zbliżania się ku socjalizmowi. Dawał on poczucie niezależności, stabilności i pewnej wygody, odsuwając jednocześnie rewolucyjne plany na daleką przyszłość 
tach odrzucenia przez SPD klasowego ekskluzywizmu, przekształcenia się w partię „ludową" i zdecydowanego zaangażowania się w istniejący system w celu jego stopniowej transformacji „od środka”. Socjalistyczny „cel” z tej perspektywy stawał się mało istotny. Róża Luksemburg z kolei, pozostając pod wrażeniem rosyjskiej rewolucji z 1905 roku, postulowała przejście przez SPD do ofensywnej taktyki, odrzucając zarówno samoizolację, jak i plan Bernsteina. Zamiast tego, nawoływała do zniszczenia albo chociaż mocnego nadwerężenia istniejącego systemu za pomocą nowej broni, jaką był strajk masowy ${ }^{12}$. Podobne poglądy głosili wówczas również inni teoretycy wyłaniającej się powoli z europejskiego ruchu socjalistycznego rewolucyjnej lewicy.

\section{„Obrońcy ojczyzny”}

Wszystko to jednak były tylko spory teoretyków, socjaldemokracją natomiast rządzili w przededniu wojny partyjni funkcjonariusze i związkowi biurokraci. To właśnie za ich sprawą socjaldemokratyczna frakcja parlamentarna poparła 4 sierpnia 1914 roku przyznanie rządowi kredytów wojennych. Miejsce proletariackiego internacjonalizmu i antymilitaryzmu - będących dotychczas oficjalnym stanowiskiem Międzynarodówki - zajęła idea "pokoju społecznego” i hasła walki z „półazjatyckimi, przepitymi wódką hordami kozackimi” ${ }^{13}$, gotującymi się rzekomo do podbicia „cywilizowanej” Europy. „Wielkie aspiracje moralne - pisze gorzko Walter - mowa o przekraczającej podziały narodowe solidarności i uniwersalizmie, nacisk na wspólnotę klasy robotniczej - to wszystko wydało się puste i w jednej chwili stało się niewiarygodne”.

Oprócz uwodzącej siły nacjonalizmu, która dała o sobie wówczas znać we wszystkich zaangażowanych w wojnę państwach, na tę brzemienną w skutki decyzję przywódców SPD wpłynęło jeszcze pragnienie zachowania budowanej z mozołem potężnej organizacji. Co więcej, przywódcy związkowi doskonale zdawali sobie sprawę, że w warunkach wojny dysponują potężną kartą przetargową i postanowili ją wykorzystać, lecz nie w celu sparaliżowania niemieckiej machiny wojennej, ale po to, aby zająć pozycję równorzędnego partnera dla rządu i przemysłowców, poszerzającego swoje przywileje i uprawnienia za cenę gwarancji stabilności produkcji.

Manfred B. Steger, zob. tegoż, The Quest for Evolutionary Socialism: Eduard Bernstein and Social Democracy, Cambridge 2006 (zwłaszcza strony 120-150).

12 R. Luksemburg, Strajk masowy, partia i zwiazki zawodowe, w: R. Luksemburg, O rewolucji: Rosja 1905, 1917, wybór P. Wielgosz, Warszawa 2008.

13 F. Walter, SPD, s. 43. 
Im dłużej jednak trwała wojna, tym bardziej oczywiste stawało się, że stawką nie jest „obrona ojczyzny”, lecz podbój, a dla robotników przewidziano nie rolę „partnerów”, lecz raczej frontowego mięsa armatniego albo coraz mocniej wyzyskiwanej i coraz bardziej głodującej siły roboczej. Na fali rozczarowania powstała w 1917 roku Niezależna Socjaldemokratyczna Partia Niemiec (USPD), która bardzo szybko z partii pacyfistycznie nastawionych inteligentów i radykalnych marksistowskich intelektualistów przerodziła się w masową partię robotniczą, stanowiącą uosobienie antywojennego protestu, rekrutującą swoją bazę członkowską przede wszystkim spośród młodych, dotychczas często niezrzeszonych robotników, którzy gwałtownie zradykalizowali się podczas wojny i z większą chęcią słuchali o radach robotniczych i dyktaturze proletariatu, niż o organizacji, powszechnym prawie wyborczym i błogosławieństwach demokracji ${ }^{14}$.

\section{Rewolucja na raty, czyli dramat międzywojennego socjalizmu}

Klęska wojenna Niemiec i upadek monarchii wyniosły do władzy „większościową" SPD, która jednak stała się zakładnikiem własnej reformistycznej taktyki, dawnej, kajzerowskiej biurokracji i konserwatywno-mieszczańskiej „milczącej większości”. „Niezależni” zaś mieli w tym czasie problem ze zdefiniowaniem własnej tożsamości - z jednej strony chcieli pozostać wierni rewolucyjnym ideałom marksizmu, z drugiej zaś krytykowali radykalizm komunistów i obawiali się rewolucyjnej przemocy. Ostatecznie próba znalezienia „trzeciej drogi” zakończyła się niepowodzeniem, a wstrząsana kolejnymi rozłamami USPD w 1923 roku połączyła się w jednolitą partię z SPD, przy czym warto pamiętać, że jeszcze wcześniej znaczna część członków tej partii przeszła do obozu komunistów.

Fakt, że to właśnie SPD była partią założycielską Republiki Weimarskiej, był, jak pisze Walter, „wielkim historycznym nieszczęściem”15. Socjaldemokracja, która czerpała dotychczas swą siłę z obietnicy radykalnej transformacji społeczeństwa, stała się paradoksalnie partią „konserwatywną”, głównym stróżem nowego porządku ${ }^{16}$, który przecież bardzo daleki był od socjalistycznego ideału, którym przez lata się karmiono. Kolejny raz dało o sobie znać dramatyczne pęknięcie, na jakim ufundowany był cały projekt demokratycznego socjalizmu - na-

14 Tamże, s. 47.

15 Tamże, s. 51.

16 W.H. Maehl, The German Socialist Party: Champion of the First Republic 1918-1933, Philadelphia 1986, s. 80.
Kolejny raz dało o sobie znać dramatyczne pęknięcie, na jakim ufundowany był cały projekt demokratycznego socjalizmu - napędzany z jednej strony utopijnym pragnieniem świata sprawiedliwego i wolnego od wyzysku, z drugiej jednak pragmatyczny i świadom własnych ograniczeń; radykalnie negujący istniejący porządek, a zarazem pragnący go naprawiać i doskonalić 
pędzany z jednej strony utopijnym pragnieniem świata sprawiedliwego i wolnego od wyzysku, z drugiej jednak pragmatyczny i świadom własnych ograniczeń; radykalnie negujący istniejący porządek, a zarazem pragnący go naprawiać i doskonalić.

W okresie międzywojennym przez moment wydawało się jednak, że problem ten udało się rozwiązać. Demokracja polityczna, teoretycznie gwarantująca sprawowanie władzy w imieniu większości społeczeństwa, w połączeniu z tezą o historycznej tendencji sprzyjającej uświadomieniu wyzyskiwanych, dawały nadzieję, że wkrótce socjaldemokracja w sposób pokojowy obejmie pełnię władzy i uczyni państwo narzędziem, za pomocą którego stopniowo dokonywać się będą socjalistyczne przekształcenia. Karl Kautsky, który wziął wówczas na siebie ciężar teoretycznego uzasadnienia takiego stanowiska, pisał, powołując się na Marksa i Engelsa, że „najważniejszym zadaniem klasy robotniczej po wywalczeniu republiki demokratycznej jest zagarnięcie w niej władzy państwowej jako narzędzia ekonomicznego wyzwolenia proletariatu" ${ }^{17}$.

Dostrzegając dramatyzm sytuacji, w jakiej znalazła się SPD w okresie międzywojennym, Walter pisze:

Można wprawdzie wyobrazić sobie, patrząc z dystansu, bardziej pragmatyczną i zdolną do rządzenia partię socjaldemokratyczną na weimarskie czasy, jednak taka partia w okresie kryzysów Republiki najprawdopodobniej bardzo źle radziłaby sobie w wyborach; rozpadłaby się jeszcze przed rokiem 1933 w sytuacji, gdyby zabrakło jej utopijnego naddatku i subkulturowej pasji jej bazy, które pozwalały przetrwać trudne czasy ${ }^{18}$.

Na tym właśnie polegała tragedia całego międzywojennego ruchu socjalistycznego, tragedia, której źródeł można byłoby chyba upatrywać po części w przegranej rewolucji lat 1918-1919.

Momentem, w którym zdawało się przez chwilę, że ta największa słabość międzywojennej lewicy europejskiej została przełamana, był bez wątpienia, pełen entuzjazmu i nadziei, okres „frontów ludowych”. Po tym, jak w 1933 roku władzę objęli naziści - paradoksalnie dokładnie tak, jak przewidywał program socjalistów, czyli poprzez podporządkowanie swoim celom instytucji państwowych w sposób demokratyczny i legalny - niemieckim socjaldemokratom przypadła jednak już tylko rola widzów. Partia została zdelegalizowana, a tysiące jej

17 K. Kautsky, Materialistyczne pojmowanie dziejów, przeł. K. Błeszyński, t. 2, cz. 1, Warszawa 1963, s. 92-93.

18 F. Walter, SPD, s. 60. 
członków podlegało represjom. Jakakolwiek poważniejsza działalność konspiracyjna w hitlerowskiej Rzeszy była niemożliwa, a socjalistyczna emigracja niemiecka koncentrowała się - bo cóż jej innego pozostało - na publicystyce, utrzymywaniu kontaktu z krajem i analizie popełnionych błędów. Przymiotnik „rewolucyjny”, jak pisze Walter, stał się odtąd ulubionym słowem socjaldemokratycznych emigrantów. Tak przypominała o sobie ta druga, radykalna, bojowa i rewolucyjna dusza socjalizmu. Praktyczne skutki tej reorientacji mogły być jednak, w tych okolicznościach, bardzo ograniczone.

\section{Czas wyborów}

Upadek Hitlera i III Rzeszy oznaczał odbudowę masowej partii i powrót z emigracji tych spośród dawnych liderów, którym udało się przeżyć. Jednocześnie jednak socjaldemokraci musieli się zmierzyć z nowymi wyzwaniami. Początkowo, nieco paradoksalnie, zdawać się mogło, że w lepszej sytuacji są ci ze wschodniej, radzieckiej strefy okupacyjnej, mogli oni bowiem wierzyć, że nadszedł historyczny moment, w którym radykalne przemiany, o których myśleli od 1933 roku, będą mogły się wreszcie dokonać. Sprzyjać temu miała likwidacja tak tragicznego dwanaście lat wcześniej rozbicia ruchu robotniczego na dwa zwalczające się nurty. Dążenie do zjednoczenia komunistów i socjalistów było początkowo niezwykle silne, a nadzieje z tym związane bardzo duże. Im dłużej jednak trwała radziecka okupacja, tym mniejszy był entuzjazm sporej części socjalistów wobec perspektyw zjednoczenia. Uruchomionego procesu, mocno wspieranego przez komunistów, nie dało się już jednak powstrzymać. Powstała w 1946 roku SED, która z miesiąca na miesiąc podlegała stopniowej „stalinizacji”, pękać zaczęły dawne więzi środowiskowe, a część spośród zawiedzionych socjaldemokratów wybierała bierność i odsuwała się od polityki. Inni, a było ich niemało, akceptowali i wspierali nowy ład, uważając, że nawet niedoskonały i nieco koślawy „realny socjalizm” jest lepszy od politycznej impotencji dawnej SPD ${ }^{19}$.

W zachodnich Niemczech dylemat wpisany w naturę demokratycznego socjalizmu rozwiązano w odwrotny sposób. Program uchwalony na zjeździe SPD w Bad Godesberg w 1959 roku był aktem kapitulacji przed systemem kapitalistycznym i rezygnacją z rewolucyjnych marzeń. Nim to jednak nastąpiło, SPD długo szukała swojego miejsca

19 Tamże, s. 99-100. 
w Republice Federalnej. Odbudowano dawne struktury organizacyjne, przystąpiono do odtwarzania dawnych środowiskowych więzi, a w komitetach partyjnych i zarządach związków znaczną część miejsc zajęli „wypróbowani funkcjonariusze z lat dwudziestych”. „Było tak - pisze Walter - jak gdyby czas się zatrzymał" ${ }^{20}$. I tak jak wcześniej, SPD była apatyczna i bierna; podczas gdy na partyjnych zebraniach powtarzano hasła i postulaty łudząco podobne do tych z lat dwudziestych i trzydziestych, Republiką rządziła Adenauerowska CDU. Kolejne wyborcze porażki rodziły frustrację, i to właśnie z niej wyrósł najpierw program godesberski i pragmatyzm socjaldemokratów, a w konsekwencji później również idea partii „nowego środka”.

Dokonującą się w kolejnych powojennych dekadach zmianę oblicza SPD Walter tłumaczy również postępującą mediatyzacją polityki, indywidualizacją i konsumpcyjnym stylem życia pokoleń powojennych, a także powolnym kurczeniem się szeregów przemysłowej klasy robotniczej, stanowiącej tradycyjnie bazę społeczną socjaldemokracji. Początkowo jednak wydawać się mogło, że transformacja SPD w nowoczesną catch-all party zakończy się wielkim sukcesem. Z jednej strony bowiem, od połowy lat sześćdziesiątych SPD dumna mogła być ze swej politycznej skuteczności, a z drugiej, przynajmniej w pierwszej połowie lat siedemdziesiątych, ze zdolności do rozbudzania społecznego entuzjazmu i nadziei na zmiany. Jednak gdy charyzmatycznego Brandta zastąpił pragmatyczny do bólu Schmidt, dawny entuzjazm uleciał, a po rozbudzonych nadziejach przyszły rozczarowania. Lata osiemdziesiąte i początek dziewięćdziesiątych upłynęły pod znakiem poszukiwania nowej formuły programowej i nowego przywódcy. To, jak szybko w tym czasie kręciła się karuzela liderów, w sposób najbardziej wymowny pokazuje kryzys, w jakim znalazła się SPD. Z jednej strony próbowano ratować resztki wpływów w środowiskach robotniczych i wśród gorzej sytuowanych grup, z drugiej zaś nie chcieli socjaldemokraci zrażać do siebie tzw. klasy średniej, czyli pracowników sektora usług, drobnych przedsiębiorców, kadr zarządzających niższego szczebla itd. Wiedzieli bowiem, że bez poparcia tego „środka” wyborcza wygrana nie będzie możliwa.

Wyjście z impasu przyniosła kampania wyborcza z 1998 roku. Socjaldemokraci pokazali wówczas elektoratowi obydwa oblicza jednocześnie - Gerhard Schröder symbolizował pragmatyzm, gotowość dostosowania się do nowego ducha kapitalizmu i sprawne zarządzanie, Oskar Lafontaine zaś uosabiać miał wrażliwość społeczną i stabilizację

20 Tamże, s. 102. 
gwarantowaną przez państwo dobrobytu. W połączeniu z kunsztownie opracowaną strategią marketingową przyniosło to spektakularny wyborczy tryumf ${ }^{21}$, lecz dziś już widać wyraźnie, że była to tylko ucieczka do przodu. Odpowiedzi na pytania, komu i po co jest wciąż potrzebna socjaldemokracja - pytania, którym kończy również swą książkę Walter - wciąż nie udzielono. Chyba, że za taką odpowiedź uznać szybką przesiadkę Schrödera z miejsca przy kanclerskim biurku na wygodny fotel członka rady nadzorczej konsorcjum Nord Stream...

\section{Socjaldemokracja jako utopia konserwatywna}

Proponowana przez Waltera „biografia” SPD jest książką niesłychanie wciągającą. Napisana w świetnym stylu (słowa uznania należą się tłumaczowi, Michałowi Sutowskiemu), skupiona na tym, co ważne, a pomijająca wątki mniej istotne (jakże rzadkie to pośród historyków!) i wpisująca dzieje niemieckiej socjaldemokracji w kontekst szerszych przemian społecznych, książka Waltera stanowi najlepszy dowód na to, że historia partii politycznej niekoniecznie musi kojarzyć się z nudnym przyczynkarstwem. Każdy, kto interesuje się dziejami polskich ruchów lewicowych, po lekturze książki Waltera poczuje pewnie zazdrość, że w naszej historiografii nie możemy wciąż pochwalić się zbyt wieloma podobnymi pracami, które łączyłyby wciągający styl narracji z przenikliwością analizy i błyskotliwością w warstwie interpretacyjnej.

„Biografia” SPD pozostawia jednak pewien niedosyt. Walter cofa się przed jakąkolwiek jednoznaczną oceną stupięćdziesięcioletniej historii partii. Stroni od stanowczych sądów - w chwilach, gdy zdaje się podejmować takie próby, natychmiast przytacza argumenty mogące przemawiać za zgoła przeciwną interpretacją, za każdym razem próbuje raczej referować zróżnicowane oceny obecne w historiografii, niż opowiedzieć się po którejś ze stron sporu. Jednak za proponowaną przez niego opowieścią o pomyłkach i słabościach socjaldemokracji oraz jej liderów zdaje się mimo wszystko kryć niewyartykułowana wprost wizja wytęsknionej partii socjaldemokratycznej, która z jednej strony byłaby pragmatyczna, nie cofała się przed współudziałem we władzy i potrafiła zdobyć zaufanie tzw. klasy średniej, z drugiej zaś posiadającej silną bazę społeczną, wyraźne kontury ideowe i konsekwentnie reprezentującej interesy najsłabszych. Słowem, takiej SPD, która jednocześnie byłaby zakorzeniona społecznie jak za czasów Bebla, dawałaby

21 Tamże, s. 192-197. 
Daje tutaj o sobie chyba znać nostalgia za silną socjaldemokracją, wciąż jeszcze wyraźnie odczuwalna we współczesnej lewicy. Żywe jest przekonanie, że jakiś kolejny „zwrot na lewo”,

przypomnienie sobie o dawnych bojowych tradycjach albo wreszcie bohaterska obrona okopów świętej Trójcy zachodniego państwa dobrobytu przed neoliberalną ofensywą spowoduje „odrodzenie" socjaldemokracji,

a rozsądny człowiek będzie miał znów na kogo zagłosować nadzieję zmiany jak za czasów Brandta, i zachowywałaby programową elastyczność jak w czasach Schrödera. Czy to jednak możliwe?

Daje tutaj o sobie chyba znać nostalgia za silną socjaldemokracją, wciąż jeszcze wyraźnie odczuwalna we współczesnej lewicy ${ }^{22}$. Żywe jest przekonanie, że jakiśs kolejny „zwrot na lewo”, przypomnienie sobie o dawnych bojowych tradycjach albo wreszcie bohaterska obrona okopów świętej Trójcy zachodniego państwa dobrobytu przed neoliberalną ofensywą spowoduje „odrodzenie” socjaldemokracji i... świat będzie taki, jak dawniej, a rozsądny człowiek będzie miał znów na kogo zagłosować. Coraz trudniej jednak oprzeć się wrażeniu, że jest to myślenie w gruncie rzeczy konserwatywne, żywiące się nadzieją, że uda się zatrzymać, a może nawet cofnąć koła historii.

Socjaldemokrację traktować należałoby chyba - pozostając w zgodzie z fundamentalnymi zasadami myślenia marksistowskiego - jako fenomen historyczny, ruch, który mógł się zrodzić w pewnych określonych warunkach i który prędzej czy później zniknie albo ulegnie marginalizacji. Socjaldemokracja świetnie radziła sobie w warunkach zinstytucjonalizowanego konfliktu klasowego w kapitalizmie przemysłowym. Lista jej sukcesów (współdzielonych często z innymi ruchami) jest długa - począwszy od powszechnego prawa wyborczego, poprzez prawa pracownicze i demokratyzację stosunków społecznych, a na instytucjach państwa dobrobytu skończywszy. Nie jest jednak winą przypadku, „zdrady” przywódców czy tylko przygodnych błędów, że wraz ze schyłkiem kapitalizmu przemysłowego podupadać zaczęła również socjaldemokracja, a jej liderzy podejmować zaczęli coraz bardziej desperackie, nieskoordynowane i wewnętrznie sprzeczne próby ratowania tonącego okrętu. A skoro tak, to czy socjaldemokratyczny projekt, który pierwotnie miał być „rewolucją od środka”, a ostatecznie zmienił się w narzędzie sprzyjające utrzymywaniu emancypacyjnych dążeń w granicach zakreślonych przez porządek kapitalistyczny, nie powinien zostać wreszcie bez żalu pożegnany, jako przeszkoda blokująca wszelkie próby pomyślenia świata „po kapitalizmie”?

Warto zwrócić uwagę, że zasygnalizowane już wcześniej wewnętrzne pęknięcie, charakterystyczne dla projektu socjalizmu demokratycznego, było zarazem źródłem jego słabości (bierność i skłonność do izolacji, które dawnej SPD zarzuca Walter), jak i jego siły. Socjaldemokracja przez dekady, w imię marzenia o lepszym i radykalnie innym świecie, konsekwentnie starała się ulepszać ten istniejący. Dialektyka reformy

22 Zob. Socjaldemokracja? Tak! Ale jaka?: Z Sheri Berman rozmawia Michat Sutowski, „Krytyka Polityczna” 2013, nr 33. 
i rewolucji, czy też może - ujmując rzecz dokładniej - reform i groźby rewolucji, przez lata napędzała socjaldemokratyczny projekt. Jednak gdy socjaldemokracja przestała „straszyć”, a marzenie o świecie wolnym od wyzysku i sprawiedliwym uznano za wstydliwą pozostałość po młodzieńczej naiwności, zniknęło również to wewnętrzne napięcie, a paliwo, dzięki któremu socjaldemokracja poruszała się naprzód, zaczęło się wyczerpywać.

Oczywiście, deradykalizacja socjaldemokracji i utrata emancypacyjnego potencjału tkwiącego w tym ruchu, nie była wcale od początku zdeterminowana. Nie jest to też konsekwencja jednostkowych błędnych decyzji, jak zdają się przypuszczać niektórzy naiwni krytycy jej współczesnej postaci. Jest to natomiast rezultat - co potwierdza również pośrednio książka Waltera - szeregu mocno uwarunkowanych strukturalnie $^{23}$, wyborów.

Już w 1894 roku zaniepokojony Engels, dostrzegając ten problem, pisał do Lafargue'a: "Jest nieszczęściem wszystkich partii skrajnych, gdy zbliża się dla nich czas, aby stały się „realne”. [...] Nasza partia nie może przekroczyć pod tym względem pewnej granicy, tak, aby nie zdradziła samej siebie. Wydaje mi się, że zarówno we Francji, jak i w Niemczech, dotarliśmy już do tego punktu" ${ }^{24}$. Z czasem socjaldemokraci, skądinąd w dobrej wierze i zgodnie z wyzwaniami walki klasowej w kapitalizmie przemysłowym, koncentrować zaczęli swoją uwagę na budowie silnej, sprawnej i hierarchicznej organizacji, ich retorykę coraz mocniej przenikać zaczął progresywizm, a historię postrzegać zaczęli w mocno ewolucjonistycznej perspektywie. To jednak perspektywa ludzi, którym się nie spieszy. Tych, którzy mają czas. Dzisiaj, w obliczu głębokiego kryzysu kapitalizmu, tego czasu nie mamy już jednak zbyt wiele.

23 Zob. A. Przeworski, Capitalism and Social Democracy, Cambridge 1986.

24 Cyt. za J. Polasky, The Democratic Socialism of Emile Vandervelde: Between Reform and Revolution, Oxford 1995, s. 22 (fragmentu tego nie odnaleziono w polskim wydaniu Dziet Marksa i Engelsa).
A skoro tak, to czy socjaldemokratyczny projekt, który pierwotnie miał być „rewolucją od środka”,

a ostatecznie zmienił się w narzędzie sprzyjające utrzymywaniu emancypacyjnych dążeń w granicach zakreślonych przez porządek kapitalistyczny, nie powinien zostać wreszcie bez żalu pożegnany, jako przeszkoda blokująca wszelkie próby pomyślenia świata „po kapitalizmie”? 
KAMIL PISKAŁA - doktorant w Katedrze Najnowszej Historii Polski UŁ. Jego zainteresowania badawcze koncentrują się wokół historii polskiej lewicy XIX i XX wieku, symbolicznych aspektów funkcjonowania ruchu robotniczego, a także tradycji środkowoeuropejskiego marksizmu. Ponadto zajmuje się dziejami polskiej międzywojennej myśli politycznej, teoriami rewolucji oraz peryferyjnymi dyskursami modernizacyjnymi pierwszej połowy XX stulecia. Młodość spędza zgarbiony nad zakurzonymi papierami w archiwum albo starymi książkami w bibliotecznych czytelniach. Związany z łódzkim klubem „Krytyki Politycznej”, w „Praktyce Teoretycznej" redaktor tematyczny w zakresie nauk historycznych.

\section{Dane adresowe autora:}

Kamil Piskała

Katedra Historii Polski Najnowszej UŁ

ul. Kamińskiego 27a, 90-219 Łódź

e-mail: kamil.piskala@gmail.com

\section{Cytowanie:}

K. Piskała, Dwie dusze socjaldemokracji, „Praktyka Teoretyczna” nr 3(9)/2013, http://www.praktykateoretyczna.pl/PT_nr9_2013_Po_kapitalizmie/13.Piskala.pdf (dostęp dzień miesiąc rok) 